\title{
Modern sedimentary processes along the Doce river adjacent continental shelf
}

\author{
Processos sedimentares modernos ao longo da plataforma \\ continental adjacente à desembocadura do rio Doce
}

\author{
Valéria da Silva Quaresma ${ }^{1 *}$, Geórgia Catabriga ${ }^{1}$, Silvia Nossa Bourguignon ${ }^{1}$, \\ Estefânia Godinho' ${ }^{1}$, Alex Cardoso Bastos ${ }^{1}$
}

\begin{abstract}
In areas of the continental shelf where sediment supply is greater than the sediment dispersion capacity, an extensive terrigenous deposits and consequently submerged deltas can be formed. The Eastern Brazilian shelf is characterized by the occurrence of river-feed deltas in between starving coasts. Herein, modern sedimentary processes acting along the Doce river adjacent continental shelf are investigated. The main objective was to understand the shelf sediment distribution, recognizing distinct sedimentary patterns and the major influence of river sediment discharge in the formation of shelf deposits. The study used 98 surficial samples that were analyzed for grain size, composition and bulk density. Results revealed 3 distinct sectors: south - dominated by mud fraction with a recent deposition from riverine input until $30 \mathrm{~m}$ deep and from this depth bioclastic sands dominate; central-north - sand-mud dominated, been recognized as a bypass zone of resuspended sediment during high energy events; and north - relict sands with high carbonate content. The modern sedimentation processes along the Doce river continental shelf is dominated by distinct sedimentary regimes, showing a strong fluvial influence associated with wave/wind-induced sediment dispersion and a carbonate regime along the outer shelf. These regimes seem to be controlled by the distance from the river mouth and bathymetric gradients.
\end{abstract}

KEYWORDS: Coastal delta; Sediment dynamics; Doce river; Continental shelf.
RESUMO: Deltas submersos e extensos depósitos sedimentares terrigenos podem ser formados em áreas da plataforma continental, onde o suprimento sedimentar é maior do que a sua dispersão. A plataforma leste brasileira é caracterizada pela presença desses deltas entre áreas de baixo aporte sedimentar, aqui denominadas como áreas famintas. Neste trabalho, os processos sedimentares que ocorrem ao longo da plataforma continental adjacente à desembocadura do rio Doce foram investigados. Dessa forma, o principal objetivo desta pesquisa foi entender a distribuição sedimentar na plataforma em questão, reconhecendo padröes distintos de sedimentação, considerando a influência do aporte fluvial na formação desses depósitos. Para tal, foram realizadas análises granulométrica, composicional e de densidade em 98 amostras de sedimento superficial. Os resultados mostraram 3 setores distintos: sul - dominado pela fração lamosa ligada a uma deposiçāo recente e oriunda do aporte fluvial, que se extendia até a profundidade de $30 \mathrm{~m}$, a partir da qual se observa o domínio de sedimento bioclástico; central-norte - dominado por areia lamosa, sendo reconhecido como uma zona de "passagem" do sedimento ressuspendido durante eventos de alta energia; e norte - presença de areias relíquias com alto teor de carbonato. O processo sedimentar moderno ao longo da plataforma continental em estudo é dominado por regimes sedimentares distintos, mostrando uma forte influência fluvial associada à dispersão sedimentar induzida pela ação de ventos e ondas, além de apresentar um domínio carbonático na plataforma externa. Os fatores controladores desses regimes estäo relacionados com o gradiente batimétrico e a distância da desembocadura do rio.

PALAVRAS-CHAVE: Delta costeiro; Sedimento dinamico; Rio Doce; Plataforma continental.

${ }^{1}$ Environmental Oceanography Postgraduate Program, Universidade Federal do Espírito Santo - UFES, Vitória (ES), Brazil. E-mails: vdsquaresma@gmail.com/ valeria.quaresma@ufes.br,georgia.oceanografia@gmail.com, silviabourg@hotmail.com, teteoceano@gmail.com, alexcardosobastos@gmail.com

*Corresponding author.

Manuscript ID: 30274. Received: 03/31/2015. Approved: 10/13/2015. 


\section{INTRODUCTION}

Modern shelf morphology and sediment distribution is strongly influenced by processes acting in different time scales. Short-term processes such as wave-current induced sediment transport, associated with inter-annual variations in sediment supply, shape the seabed morphology and control sediment dispersion. On the other hand, long-term processes like relative sea-level changes, associated with time-integrated sediment supply, control the sedimentary system, defined by Gao and Collins (2014) as a set of deposits formed in one geomorphological environment, including coastline transgression/regression and facies distribution.

In low-latitude regions, biogenic carbonate sedimentation dominates, but, in some cases, terrigenous sediment supply may supplant this regime, leading to differentiation in the sedimentation pattern (Nittrouer et al. 2007). These situations are common in areas where fluvial processes control the sediment supply to the shelf. In areas where sediment supply is greater than sediment dispersion capacity, extensive terrigenous deposits and consequently submerged deltas can be formed. Moreover, episodic events, such as heavy flooding, may lead to an uneven supply. Thus, during catastrophic events or seasonal behavior, the sediment supply to the shelf can be increased, and variations in sediment grain size can also occur. For example, during periods of heavy rainfall, the contribution of finer fractions (e.g. mud) would be greater than in dry periods. In addition to river supply control, the sedimentary pattern can still be influenced by the coastal dynamics itself (Nitrouer et al. 2007).

According to Dominguez (2004), the Brazilian east coast receives a considerable amount of sediments due to the humid climate and the presence of large rivers that drain a mountainous area. This region was classified as deltaic coast dominated by waves, mainly characterized by beach ridge coastal plains resulted from the interaction of historical shifts of river mouth position, relative sea-level changes and longshore drift pattern variations. These changes were mainly controlled by atmospheric circulation and river discharge (Dominguez \& Wanless 1991; Dominguez et al. 1992; Dominguez 2004).

The Doce river delta (northern coast of the Espírito Santo State) is one example of the deltaic systems situated along the eastern Brazilian coast (Dominguez 2004). The influence of the Doce river sediment discharge along the coast and on the adjacent continental shelf was reported by Albino and Suguio (2010). These authors studied the modern sedimentation processes and morphodynamics of Doce river mouth adjacent beaches (deltaic plain of the Doce) and identified different sedimentary sources and hydrodynamic processes that are influenced by the river sediment discharge, carbonate sedimentation and meteorological events.

Despite the recognition of the influence of the Doce river in the adjacent inner shelf and coastline sedimentation, not much is known about the deposits formed by the fluvial input. The majority of the research developed in the area is generally related to technical reports in order to meet the environmental regulations, or to underpin the economic activities in the area. A scientific gap still exists in terms of a better understanding on the formation of the eastern Brazilian river-delta deposits along the inner shelf and how the local sediment dynamics influence the facies distribution.

The lack of data in the study area is a serious matter and insufficient to generate effective conclusions about the sediment dynamics on the shelf and its deposits. Due to the regional growth and the presence of oil and gas reserves on the continental shelf, this information become vital to the establishment of management plans and environmental control impacts, as well as being fundamental to the exploitation of living and mineral resources. Therefore, this work aimed to contribute to a regional recognition of prevailing sedimentary processes acting along the Doce river adjacent inner shelf.

Herein, we investigate the surface sediment distribution along the adjacent Doce River Inner Shelf (DRIS), in order to understand modern sedimentary processes and to discuss the importance of the fluvial sediment input to the shelf.

\section{METHODOLOGY}

A total of 98 surface samples were collected using a Van Veen grab sampler. The sampling stations were defined based upon bathymetric and morphological gradients. Samples were collected from the deltaic lobe to the outer shelf, encompassing water depths from 10 to $70 \mathrm{~m}$ (Fig. 1).

Sedimentological analysis included grain size, carbonate content and surface bulk density. The determination of surface bulk density was only carried out in 51 samples (about half of the total samples), due to water loss during the field collection. Bulk density was defined using the equation below, from Amos and Sutherland (1994):

$\mathrm{Ds}=\mathrm{PS} / \mathrm{VS}$

Here, Ds is surficial bulk density $\left(\mathrm{kg} / \mathrm{m}^{3}\right)$, PS is the dry sediment weight $(\mathrm{kg})$ and VS is wet sediment volume $\left(\mathrm{m}^{3}\right)$.

After removal of the salt, the muddy fraction was separated from the sand fraction/gravelly fraction through the 
wet sieving in a $63 \mu \mathrm{m}$ sieve. The sand/gravel fractions were then subjected to mechanical sieving in 0.5 phi intervals, and the mud fractions were analyzed by a laser granulometer (Malvern Masterzise 2000). Calcium carbonate content was determined by dissolving the $\mathrm{CaCO}_{3}$ with hydrochloric acid at $10 \%$.

\section{RESULTS}

\section{Sediment distribution}

Three sectors were recognized based upon distinct sediment characteristics along the DRIS: south - from the Doce river mouth to the southern boundary of the study area; central-north - on the stretch from the Doce river mouth up to $25 \mathrm{~km}$ northward; and north - extending for approximately $28 \mathrm{~km}$ from the central-north sector limit (Fig. 2). Based on this, the results are described considering these three sectors.

\section{Grain size and Calcium Carbonate content}

South sector presented the greatest mud content, reaching up to $90 \%$ in some samples. The highest content for clay-component size was also observed in this sector (around 20\%) (Fig. 3). This muddy deposit occurs from 10 to $30 \mathrm{~m}$ deep. Seaward (depth $>30 \mathrm{~m}$ ), fine and very fine terrigenous sands become predominant. In terms of carbonates content, the average is around 20 and $15 \%$

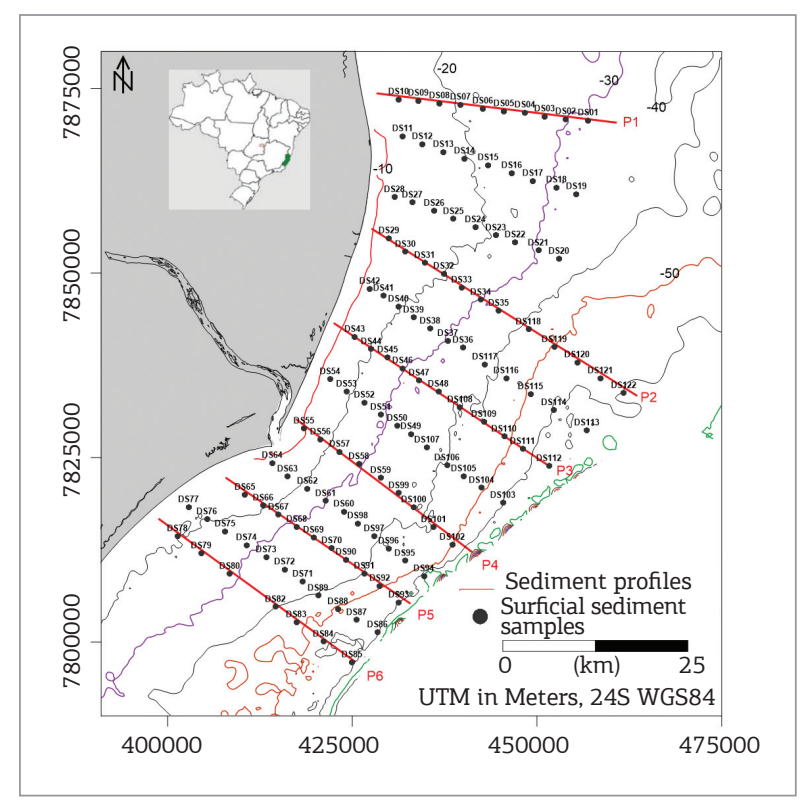

Figure 1. Location of the study area. Map showing the location of the samples presented in this study represented by black dots along a red line. DSx represents the sample label. The depth lines show a contour each 10 m depth. Coordinates are in UTM, Datum WGS84, 24S. between 30 and $40 \mathrm{~m}$. In areas deeper than $40 \mathrm{~m}$, carbonate content increases significantly, reaching up to $70 \%$ (at the southern limit).

In the central-north sector, the presence of a muddy deposit is still observed up to the $40 \mathrm{~m}$ water depth; however, mud content is lower (45-50\%) when compared with the southern sector (Fig. 4). Clay content did not exceed $10 \%$. Fine to very fine terrigenous sands comprise up to $20 \%$. Medium terrigenous sands are present ( $45 \%$ in some samples) between 30 and 40 m water depths. Deeper than $40 \mathrm{~m}$, mud content decreases significantly, showing less than $20 \%$. In general, fine to very fine terrigenous sands dominate, especially between depths of 30 and $50 \mathrm{~m}$. In areas deeper than $50 \mathrm{~m}$, the gravel fraction becomes more important, reaching $30 \%$ of the samples content. Note that in these deeper areas the carbonate content is higher, reaching up to $80 \%$. According to the visual description, these samples were composed by bioclastic gravel/coarse sands and living rhodoliths.

In the north sector, grain size distribution is more complex. Following a bathymetric gradient, there is no predominant grain size up to $20 \mathrm{~m}$ water depth. Grain size varies from gravel (about 20\%) to sand (40\%) and mud (about 40\%) (Fig. 5). Between 20 and 30 m water depths, medium sand and mud predominate with a carbonate content of up to $20 \%$. Between 30 and $40 \mathrm{~m}$ water depths, mud content reaches up to $50 \%$. Deeper than $40 \mathrm{~m}$, despite the reduced number of samples, carbonate content reaches up to $80 \%$, and living rhodoliths occur in combination with mud.

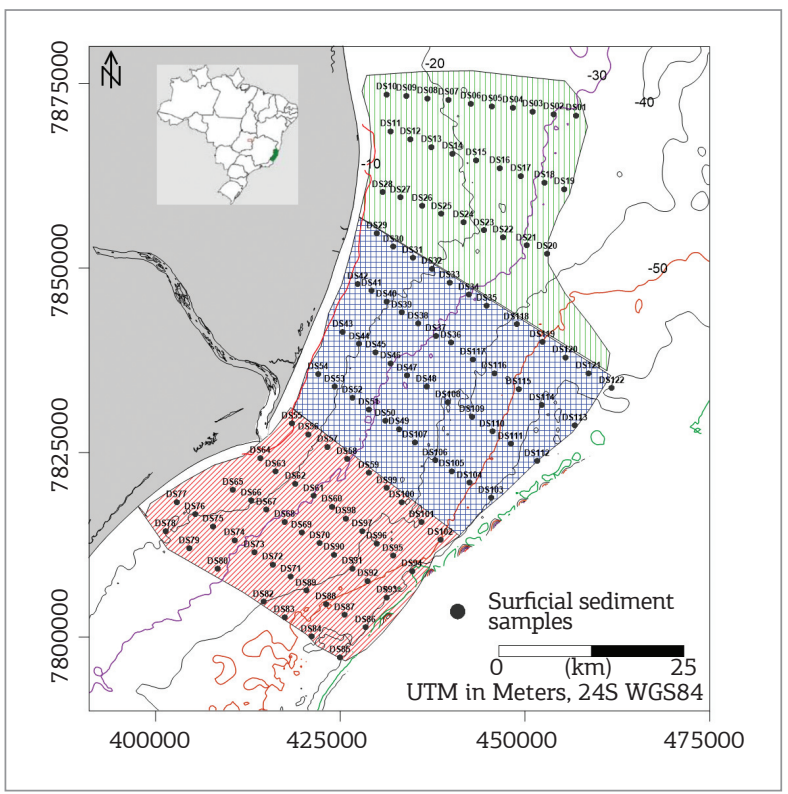

Figure 2. Map showing the location of the three distinct sectors along the Doce River adjacent shelf: south, central-north and north. 


\section{Surface bulk density}

Analyses of surface bulk density were restricted to samples collected at depths lower than $40 \mathrm{~m}$. The results showed a clear sectorization of deposits with distinct bulk densities values associated. The distribution of these deposits is geographically related to the Doce river mouth.

Southward from the river mouth, bulk density values ranged between 1,380 and $1,500 \mathrm{~kg} / \mathrm{m}^{3}$ (Fig. 6). In most samples, these values are related to higher mud concentration (Figs. 3 and 6). Northward from the river mouth, bulk density measurements presented, in general, values higher than $1,500 \mathrm{~kg} / \mathrm{m}^{3}$, reaching up to or greater than $2,000 \mathrm{~kg} / \mathrm{m}^{3}$. A trend in increasing bulk density values follows the sample distance from the coast and the water depth. Usually, samples taken from 30 to $40 \mathrm{~m}$ water depths show bulk densities values higher than $1,500 \mathrm{~kg} / \mathrm{m}^{3}$. An important observation is that the samples collected in central-north and northern sector had high plasticity, and in the southern sector the samples were liquidified, indicating higher water content, indicated as well by their bulk density values. Moreover, higher bulk density values are related to lower mud content (Figs. 5 and 6).

\section{DISCUSSION}

The results revealed that the continental shelf adjacent to the Doce river mouth presents different sedimentary patterns in terms of both depth and distance from the coast. In this case, it can be considered that the sedimentation patterns are different in relation to the source of terrigenous input.

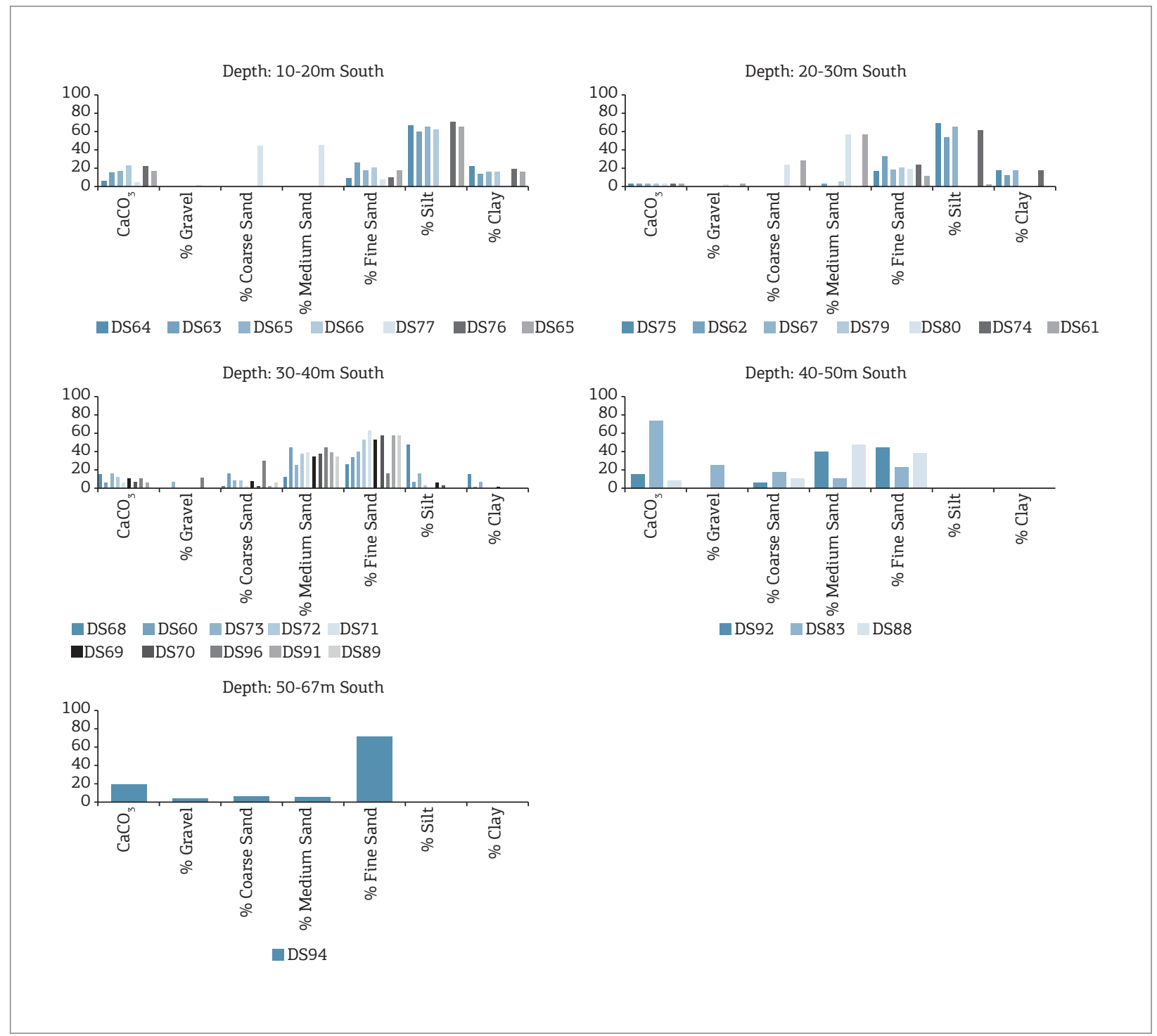

Figure 3. Diagrams showing the distribution of the grain size and carbonate content for the samples located in the southern sector, according to water depth ranges, between 10 and $67 \mathrm{~m}$. For sample location, see Fig. 1. 
In order to discuss the sedimentary pattern along the Doce river adjacent continental shelf, some modern classic continental shelf sedimentation concepts should be resumed.

The equilibrium concept discusses the fact that the continental shelf is subjected to physical forcing as winds, waves, currents and sediment input. These driving forces vary in magnitude in a short time, and, even then, the observed sediment distribution pattern shows an equilibrium ratio, that is: forcing would be controlling the surface facies distribution (Swift \&Thorne 1991). Thus, the continental shelf can be described in terms of accommodation and supply regimes. Continental shelves under an accommodation regime are subject to strong variations in sea level and/or high sediment dispersion rate, i.e., continental shelf that is subjected to marine transgression, with the presence of erosive processes and estuarine environments. Supply regime continental shelves are those with a high rate of sediment input or higher sediment grain size that would not be mobilized by the hydrodynamic energy at the site, or regressive environments with progradation and/or presence of deltaic systems (Swift et al. 1987, Swift \& Thorne 1991). In the case presented herein, the muddy deltaic lobe in the adjacent inner shelf indicates a supply regime.

Thus, the supply regime is characterized by the sediment input through a river mouth, mainly during flood periods, and by sediment transport to deeper parts across the continental shelf during storm events. In these occasions, wave orbital velocity can resuspend sediment that is swept by prevailing currents. According to Swift and Thorne (1991), during the obliquely sediment transport from the coast to

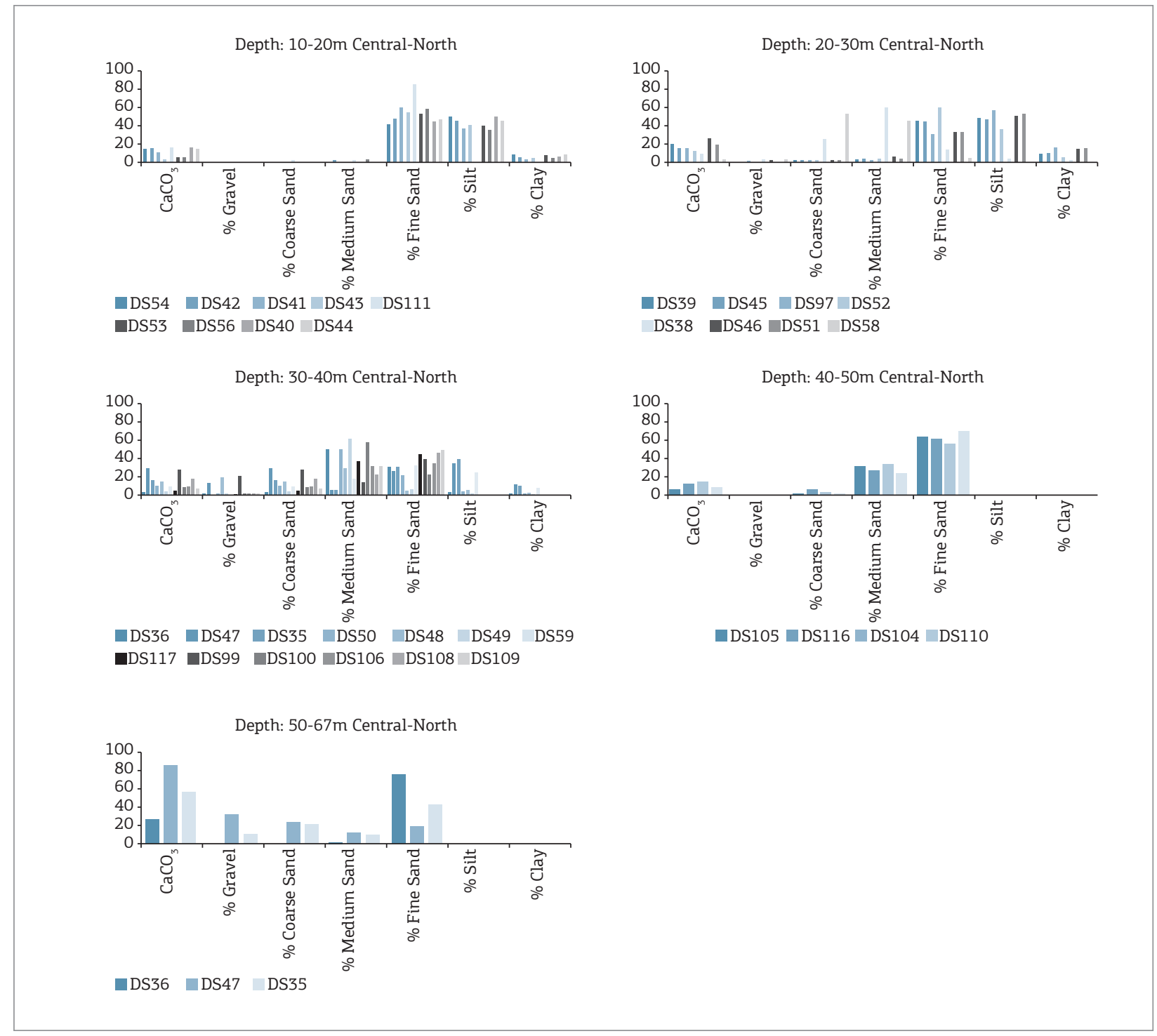

Figure 4. Diagrams showing the distribution of the grain size and carbonate content for the samples located in the central-northern sector, according to water depth ranges, between 10 and $67 \mathrm{~m}$. For sample location, see Fig. 1. 
Depth: 10-20m North
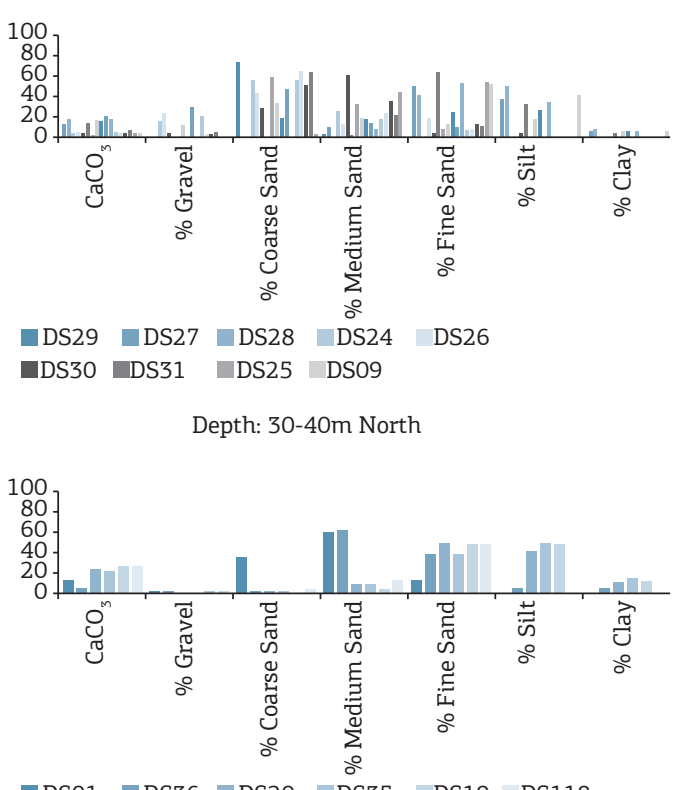

ロDS01 $\square$ DS36 DS20 DS35 DS19 DS118

Depth: 50-67m North

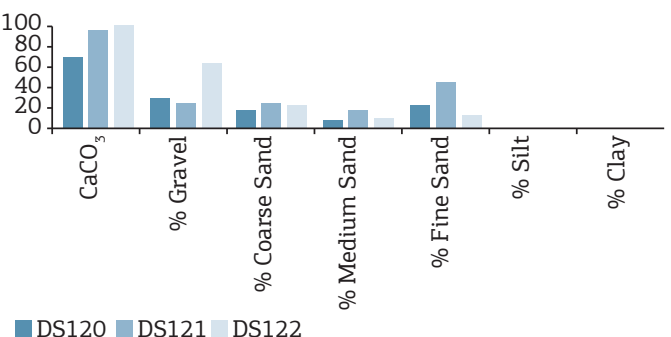

Depth: 20-30m North
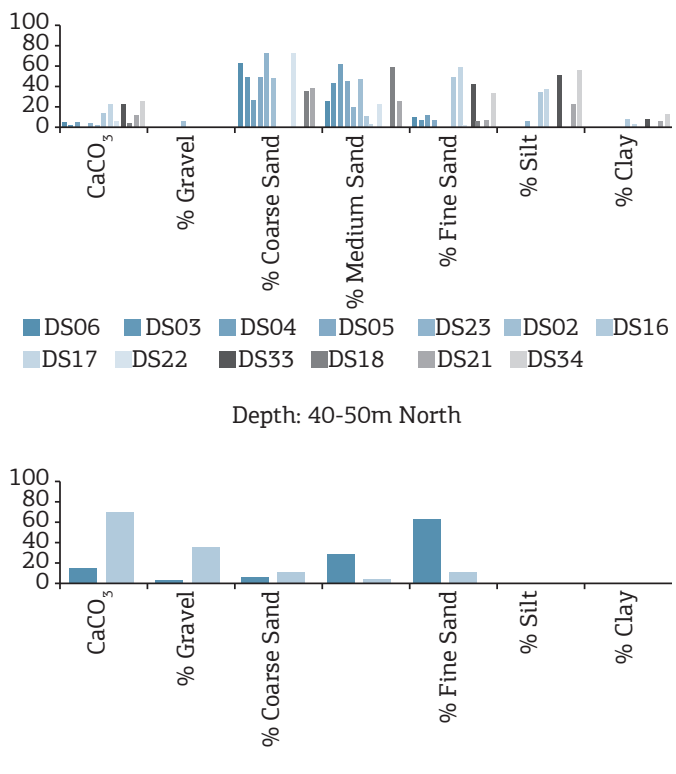

DS116 DS119

Figure 5. Diagrams of distribution of the grain size and carbonate content for the samples located in the northern sector, according to water depth ranges, between 10 and $67 \mathrm{~m}$. For sample location, see Fig. 1.
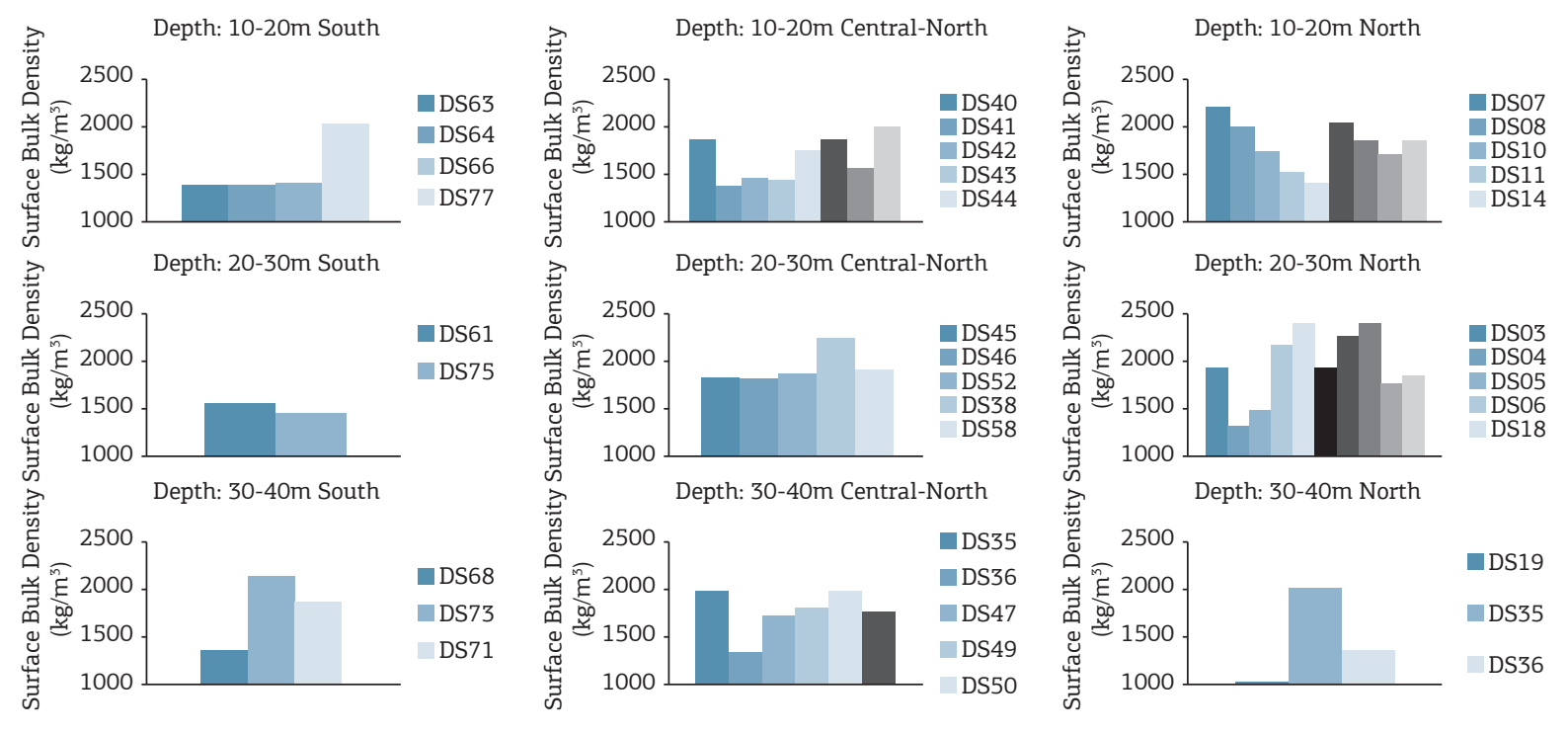

Figure 6. Diagrams showing the sediment surficial bulk density values for each sample. The stations are grouped by water depth range, between 10 and $40 \mathrm{~m}$ deep, for each sector. For sample location, see Fig. 1. 
offshore direction, it would occurs a progressive sediment selection. As result, the coarser sediment is found near the coast, and finer sediment occurs offshore. From this point of view, the grain size analysis for the study area does not show this clear pattern. Figure 7 shows sediment profiles along of the shelf presenting the relationship between mean grain size and standard deviation (values according to Folk and Ward 1957).

According to the Markov model (Swift et al. 1972), the relation between the mean grain size and standard deviation in a longitudinal section should be a decrease in grain size and a standard deviation increase from a particular site to deeper parts. The majority of the profiles for the study area does not follow the pattern described, however it should be noted that shoreface samples were not collected. The majority of the profiles showed an increase both in the mean and in the standard deviation towards offshore, and this would be directly related to the presence of carbonates (Figs. 3 to 5). Results shows that coarser sediments are located towards the mid an outer shelf with an associated increase in carbonate content (up to $80 \%$ ).

According to Albino and Suguio (2010), the river mouth adjacent beaches are composed mainly by coarse and medium terrigenous sands. These authors demonstrate that modern riverine sand input is restricted to its mouth. That would explain, in part, the absence of coarser sand fractions along the south and central-north sectors. This would take the hypothesis that terrigenous sands found in the north sector would be relict, i.e., these sands were not deposited by modern prevailing fluvial processes. An explanation is that these sands could be related to a Holocene ancient Doce river mouth, as proposed by Suguio et al. (1982), that are rarely mobilized today by prevailing wave action and/or longshore currents. The fact that this sector presents deposits with higher surface bulk density $\left(-2,000 \mathrm{~kg} / \mathrm{m}^{3}\right)$ corroborates this idea (Fig. 6). The sediments usually less consolidated are related to a recent deposition or constant resuspension (Ross \& Mehta 1989, Winterwerp \& van Kestern 2004, Mehta 2013). The fact that they have a higher bulk density, and consequent higher compaction, may indicate an older and more stable deposit. In addition, these deposits are found in a transition area for the Abrolhos continental shelf (carbonate domain) and with no major terrigenous input contribution nearby.

Another point to highlight is that in the current stage of the Doce river delta development, the sands were deposited mainly in the deltaic plain and in proximal areas to the mouth, which would limit the contribution of these fractions offshore (Holmes 1965, Fraser \& Suttner 1986, Swift \& Thorne 1991). Thus, the suspended load, which is essentially the finest fraction (fine sand and mud), is transported and deposited in the inner continental shelf, forming muddy and muddy-sandy deposits that were observed in the results.

In the central-northern and southern sectors, the terrigenous mud and mud-sand deposits dominate, extending up to $30 \mathrm{~m}$ water depth (Figs. 3 and 4). This distribution is mainly linked to the local hydrodynamic pattern, strongly influenced by the prevailing NE winds (Dominguez et al. 1983).

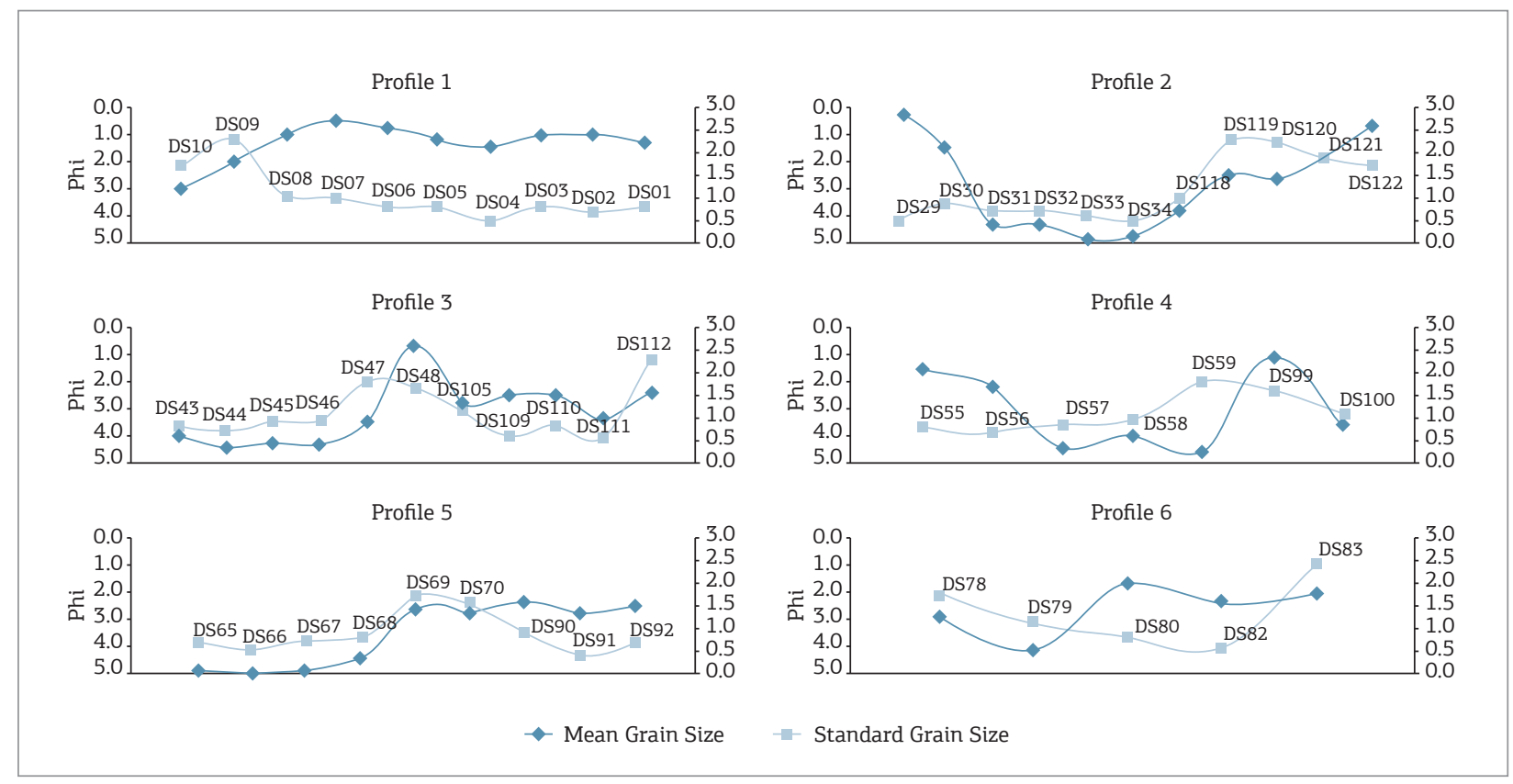

Figure 7. Relationship between mean grain size (mean) and standard deviation (SD) (values are according to Folk and Ward 1957). Results show the distribution along distinct cross shelf sediment profiles. For the location of the sediment profiles, see Fig. 1. 
In this case, considering grain size distribution, the southern sector has the highest mud content and also the higher clay content (Fig. 3). The position of this deposit, immediately at south of the river mouth, is due to the drift of the river plume, which is directed to the south, because of the dominance of northeasterly winds during fairweather. In this area, the bottom morphology is regular and smooth (Fig. 1), showing a lobe shape related to the deposition of finer material supplied by the Doce river.

Thus, a sediment distribution analysis can provide valuable information on modern sedimentary process, based on well-established theories found in the literature. Once the river plume reaches the marine environment, the particulate matter flocculation process starts. This process is due to the muddy sediment cohesive property (Mehta \& Partheniades. 1982, Berlamont et al. 1993, Torfs et al. 1996, Winterwerp \& van Kesteren 2004, Mehta 2013). When the material in suspension meets saline water, the negative clays charges are neutralized by the salts (i.e. sodium). According to Mehta and Partheniades (1982), very low range of salinity values (between 2 to $10 \mathrm{ppt}$ ) allows the process to be completed. The flocs are in turn formed by a mixture of clay, silt, very fine sand, organic matter, water and, in some cases, even gas (McAnally \& Mehta 2001, Winterwerp \& van Kesteren 2004). Thus, soon as the plume meet seawater, the process begins, leading to a rapid deposition, once the flocculation increases the settling velocity of the fine material. From this analysis, it was expected that deposition occurred immediately close the mouth, however these deposits are only observed from $10 \mathrm{~m}$ water depth.

The DRIS is located along a wave-dominated environment (Dominguez 2004). Thus, even with the flocculation process, the river discharge energy coupled with wave action would transport fine material offshore ( $>-10 \mathrm{~m}$ ), not allowing immediate deposition close to the river mouth. In the DRIS case, it was observed that fine material deposition occurs in areas deeper than $10 \mathrm{~m}$ water depth. At this depth, fine sediments would not be remobilized by fair weather waves. This would explain the presence of the muddy deposit and the lower surface bulk density values $\left(<1,500 \mathrm{~kg} / \mathrm{m}^{3}\right)$ southward from the river mouth, indicating a recent deposition and/or a process of lower consolidation phase (Figs. 6 and 8).

High density values usually are related to longer consolidation time and higher resistance to transport. As described elsewhere, dense sediment deposits have lower erosion susceptibility (Jepsen et al. 1997, Lick \& McNeil 2001, Bale et al. 2006; 2007, Amos et al. 2004, Quaresma et al. 2004, Grabowski et al. 2011). Thus, in the study area, we assumed

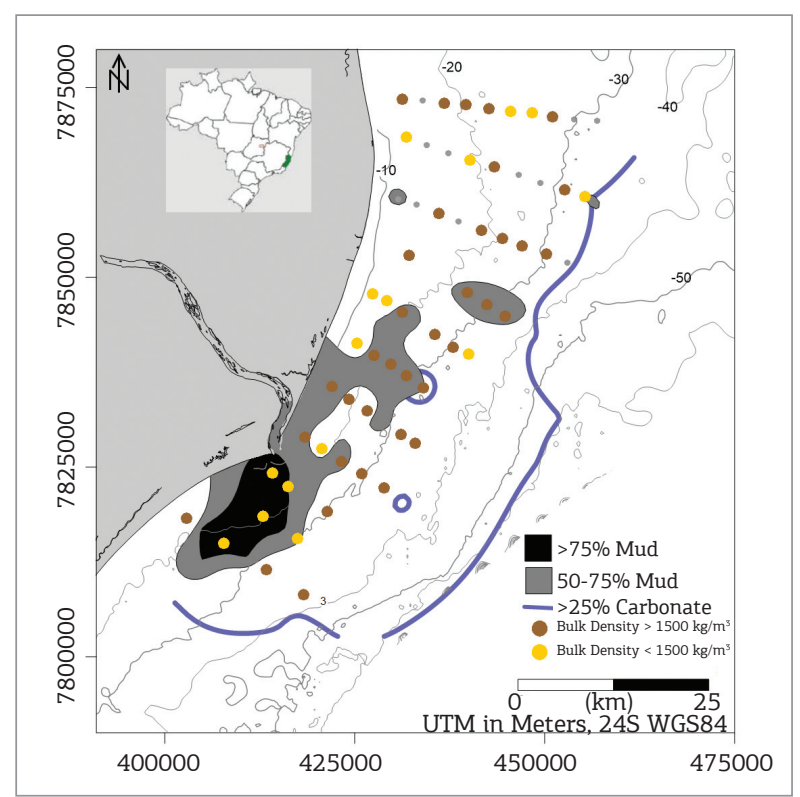

Figure 8. Map showing the main mud deposits (> 50\%) and the measured bulk density. The blue line represents the limit for sediment with more than $25 \%$ of carbonate content.

that higher density values would indicate longer consolidation time, and, in this case, values lower than $1,500 \mathrm{~kg} / \mathrm{m}^{3}$ could indicate a less stable sediment bottom, i.e, higher seabed mobility potential. Also, it is clear from our dataset that values below $1,500 \mathrm{~kg} / \mathrm{m}^{3}$ are concentrated in the shallow south sector zone.

During cold front periods, higher energy waves from the $S$ and SSE quadrant with higher wave orbital velocities could remobilize and transport fine sediments northward (Bittencourt et al. 2007). It should be noted that the $30 \mathrm{~m}$ water depth represents the depth of bed remobilization by most frequent storm waves, which in the region have a significant height of $1.5 \mathrm{~m}$ and peak period of $6.5 \mathrm{~s}$ (Bittencourt et al. 2007). Another indication of this process is the higher bulk density values northwards (Figs. 6 and 8). As stated previously, this may indicate an older consolidated muddy deposit. As the flocs are deposited, the interaction floc to floc and their own weight expel the water from the structure, leading to greater compaction of the deposit (Ross \& Mehta 1989). This entire process takes time, and the material cannot be constantly resuspended for the process to complete.

The coarser grain sizes are found in deeper regions (Figs. 3 to 5) and are most related to the presence of bioclastic and rhodoliths, showing the limitation for terrigenous sediment transport. These deeper areas have been characterized as carbonate domain beds, extending along the Espírito Santo outer shelf as described by Bastos et al. (2015). 


\section{CONCLUSIONS}

The DRIS sedimentation pattern is directly influenced by Doce river sediment supply. Riverine fine sediments are deposited to the south of the river mouth, forming a lower bulk density deposit with high mud content, comprising up to $12 \%$ of clay. The riverine modern sediment influence reduces northward, where a higher bulk density deposits are observed, associated with greater mean grain size and lower mud content. The modern riverine terrigenous deposit is characterized by a deltaic lobe ending at $30 \mathrm{~m}$ water depth. Towards offshore (water depths $>30 \mathrm{~m}$ ), sandy facies are predominant, and an increase in carbonate content is observed in areas deeper than $40 \mathrm{~m}$. Mid-outer shelf is characterized by typical marine carbonate sedimentation with the occurrence of bioclastic sand and gravel and rhodoliths.

The DRIS sedimentation pattern can be described by the presence of three sectors:

- South sector - dominated by riverine muds forming modern deposits with bulk densities lower than $1,500 \mathrm{~kg} / \mathrm{m}^{3}$ (fine sand and mud) and bioclastic sand/gravel offshore (from $40 \mathrm{~m}$ depth). During storm events, inner shelf deposits can be remobilized and transported northward.

- Central-north sector - still an area of fluvial influence, but with less intense depositional processes. This would be a bypassing area for resuspended sediment during storm events when drift is reversed due to SSE winds.
Lower clay content and an increase in bulk density values were observed. Offshore, fine to medium sands predominate, with an increase in carbonate content.

- North sector - presence of relict sands with high carbonate content. The deposits found showed the highest bulk density values $\left(>2,000 \mathrm{~kg} / \mathrm{m}^{3}\right)$, indicating older or more stable deposit.

Modern sedimentation processes along the DRIS is influenced by both fluvial and the meteoceanographic conditions (as was expected). Sediment distribution is a result of temporal changes in riverine sediment supply with inter-annual variability of meteoceanographic conditions, associated to fair weather and storm events. The integrated analysis of bulk density, grain size parameters and sediment composition has demonstrated that an immediate fine material deposition occurs at the south of the river mouth in fairweather periods ( $\mathrm{N}$ and $\mathrm{NE}$ winds), while northward transport predominates during storm events associated with SSE winds.

\section{ACKNOWLEDMENT}

This study was supported by Coordenação de Aperfeiçoamento de Pessoal de Nível Superior (CAPES)/ Ciências do Mar (Grant number 224/2010) and by Fundação de Amparo à Pesquisa do Estado do Espírito Santo (FAPES, Grant number 54682860).

\section{REFERENCES}

Albino J. \& Suguio K. 2010. Sedimentation processes and beach morphodynamics active at the Doce River mouth, Espírito Santo State, Brazil. Anais da Academia Brasileira de Ciências, 82(4):1031-1044.

Amos C.L. \& Sutherland T.F. 1994. A rapid technique for the determination of dry sediment mass from saturated marine sands. Journal of Sedimentary Research, 64(3):668-670.

Amos C.L., Bergamasco A., Umgiesser G., Cappucci S., Cloutier D., DeNat L., Flindt M., Bonardi M., Cristante S. 2004. The stability of tidal flats in Venice Lagoon - the results of in-situ measurements using two benthic, annular flumes. Journal of Marine Systems, 51:211-241.

Bale A.J., Widdows J., Harris C.B., Stephens J.A. 2006. Measurements of the critical erosion threshold of surface sediments along the Tamar Estuary using a miniannular flume. Continental Shelf Research, 26(10):1206-1216.

Bale A.J., Stephens J.A., Harris C.B. 2007. Critical erosion profiles in macro-tidal estuary sediments: implications for the stability of intertidal mud and the slope of mud banks. Continental Shelf Research, 27(18):2303-2312

Bastos A.C., Quaresma V.S., Marangoni M.B., D’Agostini D.P., Bourguignon S.N., Cetto P.H., Silva A.E., Amado Filho G.A., Moura R.L., Collins M. 2015. Shelf morphology as an indicator of sedimentary regimes: A synthesis from a mixed siliciclastice carbonate shelf on the eastern Brazilian margin. Journal of South American Earth Sciences, 63:125-136.
Berlamont J., Ockenden M., Toorman E., Winterwerp J. 1993. The characterisation of cohesive sediment properties. Coastal Engineering, 21:105-128.

Bittencourt A.C.S.P., Dominguez J.M.L., Martin L., Silva I.R., Medeiros K.O.P. 2007. Past and current sediment dispersion pattern estimates through numerical modeling of wave climate: an example of the Holocene delta of the Doce River, Espírito Santo, Brazil. Anais da Academia Brasileira de Ciências, 79(2):333-341.

Dominguez J.M.L. 2004. The coastal zone of Brazil: an overview. Journal of Coastal Research, SI39:16-20.

Dominguez J.M.L. \& Wanless H.R. 1991. Facies architecture of a falling sealevel, Doce river coast, Brazil. International Association of Sedimentologists Special Publication, 14:259-281.

Dominguez J.M.L., Bittencourt A.C.S.P., Martin L. 1983. O papel da deriva litorânea de sedimentos arenosos na construção das planícies costeiras associadas a desembocaduras dos rios São Francisco (SE/ ALO), Jequitinhonha (BA), Doce (ES) e Paraíba do Sul (RJ). Revista Brasileira de Geociências, 13(4):93-105.

DominguezJ.M.L, Bittencourt A.C.S.P., Martin L. 1992. Controls on quaternary coastal evolution of the east-northeastern coast of Brazil: roles of sea-level history, trade winds and climate. Sedimentary Geology, 80:213-232.

Folk R.L. \& Ward W.C. 1957. Brazos River Bar: A study in significance of Grain Size Parameters. Journal of Sedimentary Petrology, 27(1):3-26. 
Fraser G.S. \& Suttner L. 1986. Alluvial fans and fan deltas. Boston, Human Resources Development Corporation, 199 p.

Gao S. \& Collins M.B. 2014. Holocene sedimentary systems on continental shelves. Marine Geology, 352:268-294.

Grabowski R.C., Droppo I.G., Wharton G. 2011. Erodibility of cohesive sediment: The importance of sediment properties. Earth-Science Reviews, 105:101-120.

Holmes A. 1965. Principles of Physical Geology. London, Thomas Nelson Sons, $1288 \mathrm{p}$.

Jepsen R., Roberts J., Lick W. 1997. Effects of bulk density on sediment erosion rates. Water Air and Soil Pollution, 99(1-4):21-31.

Lick W. \& McNeil J. 2001. Effects of sediment bulk properties on erosion rates. Science of the Total Environment, 266(1-3):41-48.

McAnally W.H. \& Mehta A.J. (eds). 2001. Collisional aggregation of fine estuarial sediment. In: Coastal and Estuarine Fine Sediment Processes. Elsevier Science B.V., p. 19-39.

Mehta A.J. \& Partheniades E. 1982. Resuspension of deposited cohesive sediments beds. Proc. 18 ${ }^{\text {th }}$ Int. Conf. Coastal Eng., ASCE. 1569-1588.

Mehta A.J. 2013. An introduction to hydraulic of fine sediment transport. Singapore, World Scientific Publishing, 1039 p.

Nittrouer C.A., Austin Jr. J.A., Field M.E., Kravitz J.H., Syvitski J.P.M., Wiberg P.L. 2007. Writing a Rosetta stone: insights into continental-margin sedimentary processes and strata. In: Nittrouer C.A., Austin Jr. J.A., Field M.E., Kravitz J.H., Syvitski J.P.M., Wiberg P.L. Continental margin sedimentation: from sediment transport to sequence stratigraphy. Special Publication 37. International Association of Sedimentologists, Blackwell Scientific Publications.
Quaresma V.S., Amos C.L., Flindt M. 2004. The influences of biological activity and consolidation time on laboratory cohesive beds. Journal of Sedimentary Research, 74(2):184-190.

Ross M.A. \& Mehta A.J. 1989. On the mechanics of lutoclines and fluid mud. Journal of Coastal Research, SI5:51-61.

Suguio K., Martin L., Dominguez J.M.L. 1982. Evolução da Planície Costeira do rio Doce (ES) durante o quaternário: influência das flutuações do nível do mar. In: IV Simpósio do Quaternário do Brasil, p. 93-116.

Swift D.J.P. \& Thorne J.A. 1991. Sedimentation on continental margins, I: a general model for continental shelf sedimentation. In: Swift D.J.P., Oertel G.F., Tillman R.W., Thorne J.A. (eds). Shelf Sand and Sandstone Bodies: Geometry, Facies and Sequence Stratigraphy. Oxford, Special Publication 14, International Association of Sedimentologists, Blackwell Scientific Publications, p. 3-31.

Swift D.J.P, Ludwick J.C., Boehmer W.R. 1972. Shelf Sediment Transport, a probability model. In: Swift D.J.P., Duane D.B., Pilkey O.H. (eds). Shelf Sediment Transport: Process and Pattern. Stroudsbourg, PA, Dowden Hutchinson \& Ross, 195-223 p.

Swift D.J.P., Hudelson P.M., Brenner R.L., Thompson P. 1987. Shel construction in aforeland basin: storm beds, shelf sand bodies and shelf-slope sequences in the Upper cretaceous Mesaverde group, Book Cliffs, Utah. Sedimentology, 34:423-457.

Torfs H., Mitchener H., Huysentruyt H., Toorman E. 1996. Settling and consolidation of mud/sand mixtures. Coastal Engineering, 29:27-45.

Winterwerp J.C. \& van Kesteren W.G.M. 2004. Introduction to the physics of cohesive sediments in the marine environment. Elsevier, Developments in Sedimentology, 56.

Arquivo digital disponível on-line no site www.sbgeo.org.br 